Article

\title{
Breeding Strategies to Improve Miscanthus as a Sustainable Source of Biomass for Bioenergy and Biorenewable Products
}

\author{
John Clifton-Brown ${ }^{1, *(1)}$, Kai-Uwe Schwarz ${ }^{2}$, Danny Awty-Carroll ${ }^{1}\left(\mathbb{0}\right.$, Antonella Iurato ${ }^{1,3}$, \\ Heike Meyer ${ }^{2}$, Jörg Greef ${ }^{2}$, Jeff Gwyn ${ }^{4}$, Michal Mos ${ }^{5}{ }^{\circledR}$, Christopher Ashman ${ }^{1}$, \\ Charlotte Hayes ${ }^{1,+}{ }^{\text {, Lin Huang }}{ }^{1}$, John Norris ${ }^{1}$, Charlie Rodgers ${ }^{4}$, Danilo Scordia ${ }^{3}{ }^{10}$, \\ Reza Shafiei $^{1, \ddagger}$, Michael Squance ${ }^{1,6}$, Timothy Swaller ${ }^{4, \S}$, Sue Youell ${ }^{1}$, Salvatore Cosentino ${ }^{3}$, \\ Richard Flavell ${ }^{4}$, Iain Donnison ${ }^{1}$ (D) and Paul Robson ${ }^{1}$ (D) \\ 1 Institute of Biological, Environmental and Rural Sciences (IBERS), Aberystwyth University, Gogerddan, \\ Aberystwyth, Wales SY23 3EE, UK; dga1@aber.ac.uk (D.A.-C.); ani9@aber.ac.uk (A.I.); \\ cha4@aber.ac.uk (C.A.); Charlotte.Hayes@elsoms.com (C.H.); lsh@aber.ac.uk (L.H.); \\ john.norris99@gmail.com (J.N.); r.z.shafiei@dundee.ac.uk (R.S.); michael@physisdata.com (M.S.); \\ sueyouell@gmail.com (S.Y.); isd@aber.ac.uk (I.D.); ppr@aber.ac.uk (P.R.) \\ 2 Julius Kuhn-Institut (JKI), Bundesforschungsinstitut fur Kulturpflanzen, Bundesallee 58, 38116 \\ Braunschweig, Germany; kai-uwe.schwarz@julius-kuehn.de (K.-U.S.); heike.meyer@julius-kuehn.de (H.M.); \\ joerg-michael.greef@julius-kuehn.de (J.G.) \\ 3 Dipartimento di Agricoltura, Alimentazione e Ambiente, University of Catania, via Valdisavoia 5, 95123 \\ Catania, Italy; dscordia@unict.it (D.S.); sl.cosentino@unict.it (S.C.) \\ 4 CERES Inc., Now Land O' Lakes, 1535 Rancho Conejo Blvd, Thousand Oaks, CA 19320, USA; \\ iwypprogdirector@iwyp.org (J.G.); crodgers003@gmail.com (C.R.); tswaller11@gmail.com (T.S.); \\ richflav@msn.com (R.F.) \\ 5 Energene sp. z o.o., Plac Solny 15, 50-062 Wrocław, Poland; michalm@energene.pl \\ 6 Terravesta Ltd., South Carlton, Lincoln LN1 2RH, UK \\ * Correspondence: jhc@aber.ac.uk; Tel.: +44-1970-823191 \\ † Present address: Elsoms Wheat Ltd., Spalding, Lincolnshire PE11 1QG, UK. \\ $\ddagger \quad$ Present address: Plant sciences division, University of Dundee, Errol Road, Invergowrie DD2 5DA, UK. \\ $\S$ Present address: Genomics Institute of the Novartis Research Foundation, 10675 John Jay Hopkins Drive, \\ San Diego, CA 92121, USA.
}

Received: 18 September 2019; Accepted: 16 October 2019; Published: 24 October 2019

check for updates

\begin{abstract}
Miscanthus, a $\mathrm{C}_{4}$ perennial grass native to Eastern Asia, is being bred to provide biomass for bioenergy and biorenewable products. Commercial expansion with the clonal hybrid $M . \times$ giganteus is limited by low multiplication rates, high establishment costs and drought sensitivity. These limitations can be overcome by breeding more resilient Miscanthus hybrids propagated by seed. Naturally occurring fast growing indigenous Miscanthus species are found in diverse environments across Eastern Asia. The natural diversity provides for plant breeders, the genetic resources to improve yield, quality, and resilience for a wide range of climates and adverse abiotic stresses. The challenge for Miscanthus breeding is to harness the diversity through selections of outstanding wild types, parents, and progenies over a short time frame to deploy hybrids that make a significant contribution to a world less dependent on fossil resources. Here are described the strategies taken by the Miscanthus breeding programme at Aberystwyth, UK and its partners. The programme built up one of the largest Miscanthus germplasm collections outside Asia. We describe the initial strategies to exploit the available genetic diversity to develop varieties. We illustrate the success of combining diverse Miscanthus germplasm and the selection criteria applied across different environments to identify promising hybrids and to develop these into commercial varieties. We discuss the potential for molecular selections to streamline the breeding process.
\end{abstract}


Keywords: Miscanthus; Breeding; Perennial Biomass Crop; Wide Hybrids; Bioenergy; Bioeconomy

\section{Introduction}

Urgent action is needed to reduce levels of carbon dioxide entering the atmosphere and sequester carbon [1]. Climate change active policy makers are looking to the agriculture and forestry sectors to use the large global resource of underutilized marginal lands to massively increase biomass production and utilization and sequester carbon from the atmosphere. Perennial biomass crops (PBCs), including grasses and trees, have desirable sustainability characteristics: high output to low energy input ratios, the ability to be deployed at sufficient scale to impact fossil fuel usage and the ability to be grown economically on lower-grade land not currently needed for food production.

The $\mathrm{C}_{4}$ perennial grass Miscanthus, a close relative of sugarcane (Saccharum spp), combines these desirable characteristics and has been grown in trials in a wide range of climates, including temperate and continental climates in Europe and America [2]. The widely grown commercial M. $\times$ giganteus $(M \times g)$ is a sterile triploid hybrid collected from sympatric regions in Japan where $M$. sinensis and $M$. sacchariflorus co-exist [3]. Harvestable yields for the standard $M \times g$ range from 10 to $30 \mathrm{Mg} \mathrm{DM} \mathrm{ha}^{-1}$ depending on location and inter annual weather variations during the growing season [4]. Early molecular diversity studies in Europe [5] showed there were a handful of different clones of $M \times g$, but these represented little phenotypic diversity [6]. While highly productive in some field trials [7,8], a number of experiments showed that the original $M \times g$ hybrids were particularly susceptible to water deficit $[9,10]$. With global warming, climatic extremes are likely to become more frequent $[11,12]$ and resilience traits to both too much and too little water need to be incorporated into new hybrids. Breeding programmes need to produce hybrids that achieve high biomass with minimum inputs of water and nutrients and with resilience to both abiotic stresses from extreme weather and biotic stresses from diseases.

Over the past 20 years, Miscanthus has received sustained financial support for genetic improvement through breeding $[13,14]$ from a combination of public and private investors. Genetic improvement depends on an understanding of Genotype $\times$ Environment $(G \times E)$ interactions that determine which combination of traits would potentially result in highest yield. In conventional breeding, breeders use phenotypic selection to drive decisions for cross hybridization. Phenotypic selection, applied to both parents and progeny, focusses on final yield and quality and is normally based on morphological traits, such as shoot height and shoot densities per $\mathrm{m}^{2}$.

Underlying these traits are the physiological traits driving growth. Plant growth can be viewed as a biological solar panel: leaves intercept light, capture atmospheric $\mathrm{CO}_{2}$ and convert the assimilated carbon into structural and non-structural carbohydrates. These physiological processes with complex feedbacks are challenging to use in practical breeding.

This paper describes the practical strategies taken over the past 15 years to move Miscanthus breeding, as quickly as possible from wild accessions in Asia into the PBC of choice for large areas of marginal lands.

\section{Breeding Strategies}

The Miscanthus crop is largely undomesticated and thus for any breeding programme there are many potential traits that could be targeted for simultaneous improvement. In establishing the Miscanthus breeding programme at Aberystwyth, a long-term goal set in 2006 was to breed resilient Miscanthus that could be propagated from true seed [15]. While clonal hybrids have advantages such as fixing traits giving homogenous stands, multiplication rates for clones through rhizome splitting and nodal propagation range from 10-100, while seed multiplication rates are $>2000$. It was believed that seeded varieties were the most likely route by which sufficient area of Miscanthus plantation could be established to deliver the biomass required to generate a global impact. Resilient crops would allow 
Miscanthus to sustain higher levels of yield by matching varieties with many different environments. One major question remained, how in practice could this be done?

The first step taken was to investigate the available trait diversity within Miscanthus collections. Diverse Miscanthus germplasm was collected from European 'secondary germplasm sources' and characterized at a single site near Aberystwyth [16]. The field trial was planted with 240 genotypes and over half of these accessions had known Asian country origins. Using the site of origin data allowed geographical analysis of traits such as flowering time, and improved the understanding of how the spread of Miscanthus impacted traits of interest and of where further germplasm collections should be made [17]. Preliminary distribution maps and yield assessments emerged in the literature in 2004 [18]. These early studies highlighted the diversity of traits available within a wide distribution of Miscanthus species. In 2006, Aberystwyth began to lead expeditions to collect wild Miscanthus germplasm in Asia [19]. Over five years, one of largest $e x$-situ Miscanthus germplasm collections in the world was created with germplasm from China, Japan, Taiwan and South Korea. For each collected accession the geographical location was recorded along with local soil conditions, the environmental conditions and altitude corrected "historical" meteorological data [19].

Of the original 240 genotypes studied, two $M$. sacchariflorus accessions towered above all accessions including $M \times g$ displaying exceptional growth vigor and yield potential. Further, in situ assessments of yield at collection sites in Asia suggested that some wild accessions might out yield standard $M \times g$ and that these, subject to adequate performance trialing, could be the first new types to be commercialized. This approach was part of the 'four tracks strategy' shown in Figure 1.

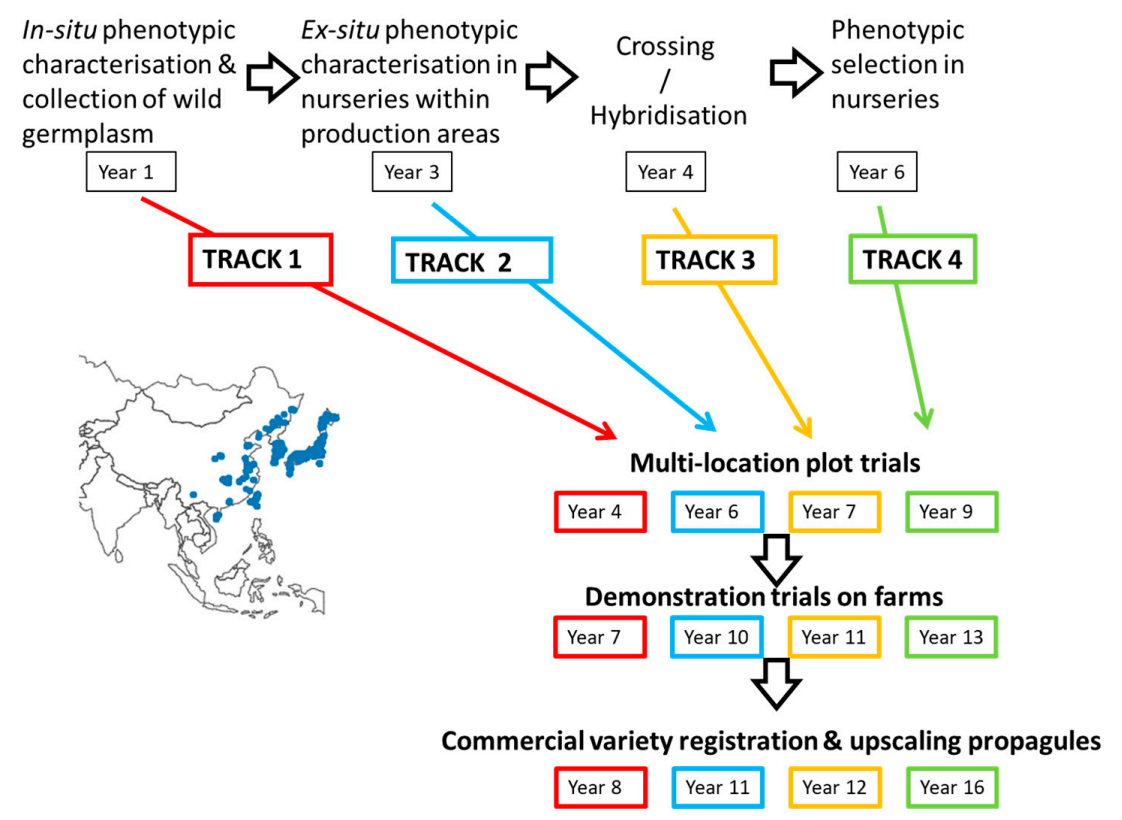

Figure 1. Four interrelated strategic 'tracks' for the development of commercial hybrids from wild Miscanthus accessions with estimates of minimum cumulative years needed to take wild germplasm through to the commercial hybrids. Inset, a map showing locations of wild germplasm collections.

Track 1. Wild population-based accessions from seed collected in Asia of M. sacchariflorus. Accessions were selected in-situ with good biomass characteristics and high seed numbers per panicle, which could be efficiently threshed resulting in multiplication rates $>2000$ propagules per plant $\left(\sim\right.$ per $\left.\mathrm{m}^{2}\right)$. Track 1 potentially represented the fastest track to expand commercial cropping areas. In spite of this, with three-year yield evaluations at multiplication plot and demonstration scales, Track 1 could only be expected to reach commercial maturity in about eight years. It was also the most risky approach, since $\mathrm{G} \times \mathrm{E}$ adaptations were not tested outside the native environments of the accessions. 
Track 2. 'Outstanding' wild genotypes of M. sinensis and M. sacchariflorus were selected ex-situ after one year's growth and successful overwintering. These accessions were upscaled with clonal propagation by in vitro tillering and placed into multi-location plot trials for yield and quality evaluation. The Aberystwyth programme recognized the value of outstanding clones because cloning fixes desirable traits, as exemplified by the commercial standard $M \times g$. Track 2 utilized selection of accessions in or near the climatic zones where the biomass was intended to be produced. However, these selections were considered as only 'intermediate varieties' because clonal propagation was likely to be too expensive and too slow in producing sufficient clones for thousands of hectares.

Track 3. 'Outstanding' genotypes (from Track 1 or 2 ) were used as parents to produce F1 hybrid progeny. These progeny were assessed directly in multi-location plot trials for yield and quality. Track 3 assumed that outstanding accessions identified from $e x$-situ nursery trials would be good parents.

Track 4. A simple breeding track that used phenotypic evaluation of the progeny of crosses (from within and between species groups) in small scale breeding nurseries trials before further testing in multi-location plot trials. The nursery trials helped inform the choice of parental combinations for upscaling of seed production and were therefore less likely to waste resources in the multi-location plot trialing, but this track was the slowest and required about 16 years.

\section{Aberystwyth Experience of Implementing Fast Tracks}

Accessions collected from Japan and China in 2007/8 were planted in Track 1 and 2 trials at three locations: UK (Aberystwyth), Germany (Braunschweig) and Italy (Sicily). These locations spanned a wide range of European climates; however, rabbit damage in the UK and irrigation problems in Italy lead to poor stand establishment, and these two sites could not be further used. At Braunschweig, the original track 1 and 2 plots produced high quality yield comparisons between standard clonal $M \times g$ and new germplasm (Figure 2). In the second growth year, three Chinese accessions of $M$. sacchariflorus matched $M \times g$ in producing $10-12 \mathrm{Mg} \mathrm{DM} \mathrm{ha}^{-1}$ (data not shown). However, after the second growing season, $M \times g$ produced not only the highest spring harvestable yields (Figure 3) but also the biomass had relatively low moisture content. The Track $1 \& 2$ trials showed that (i) the very tall $(>4 \mathrm{~m})$ Chinese accessions nearly reached their yield potential in two years, (ii) yields from the tetraploid Japanese and diploid Chinese M. sacchariflorous were comparable and (iii) $M \times g$ performed better than the new accessions in good growing years in central Germany with plenty of water and sunshine.

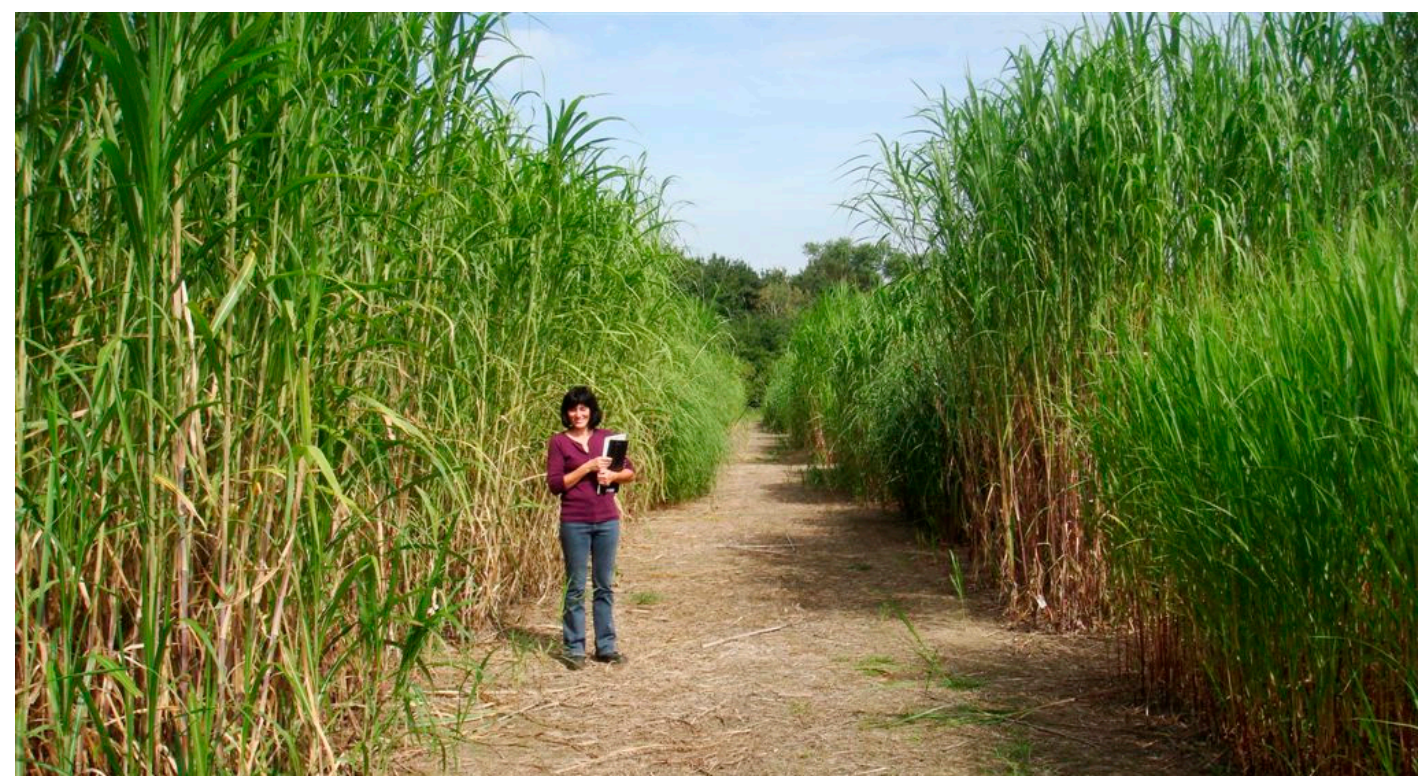

Figure 2. A view of a combined Track 1 and 2 field trial in Braunschweig, Germany in late August 2012 (Photo by Kai Schwarz, with breeding technician, Heike Meyer). 


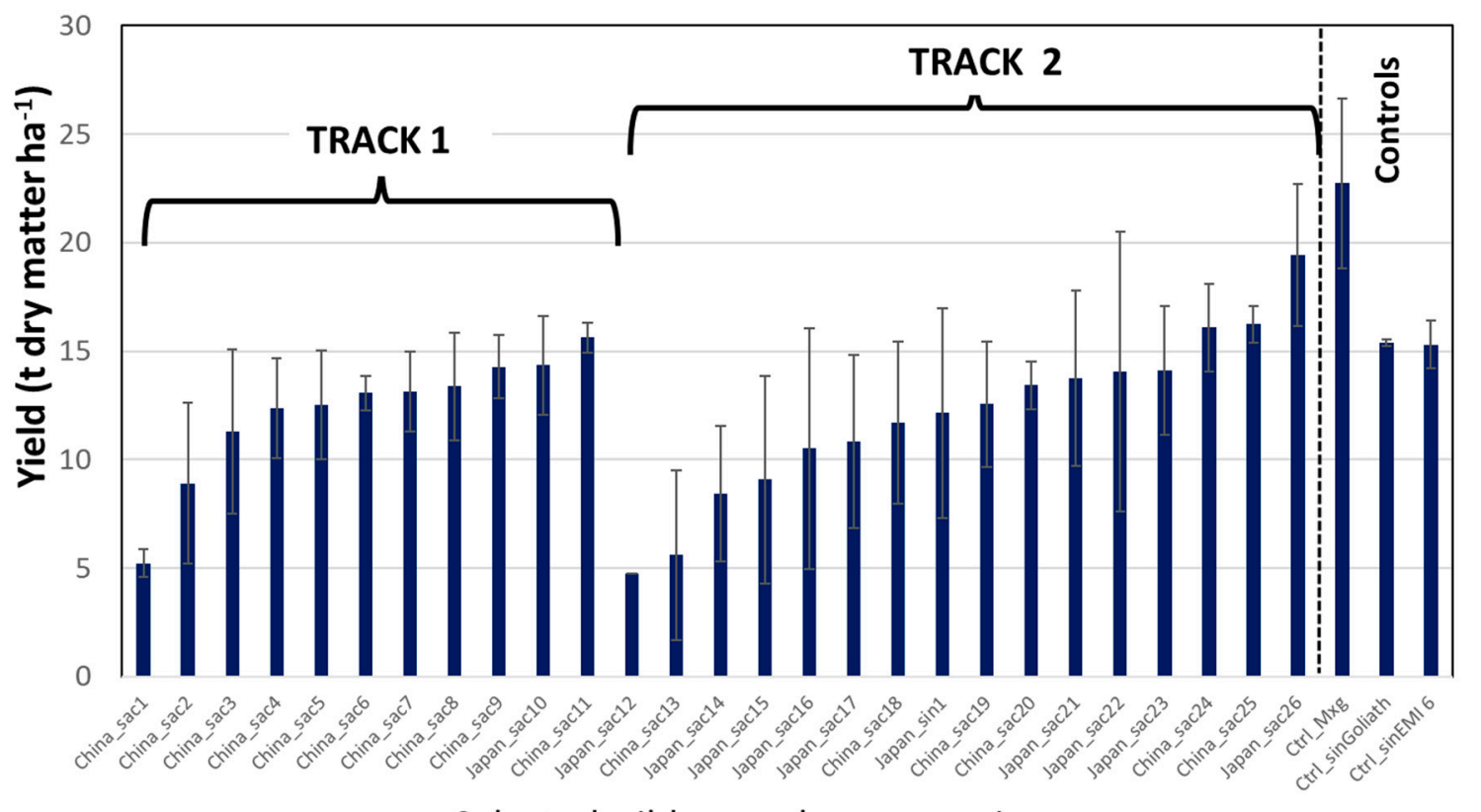

\section{Selected wild germplasm accessions}

Figure 3. Spring harvestable yield ( $\mathrm{t}$ dry matter ha ${ }^{-1}$ ) for selections from Track 1 (11 M. sacchariflorus accessions from seed) and Track 2 (16 selections, cloned by in vitro propagation) and three control genotypes (standard $M \times g$ ), M. sinensis (Goliath and EMI-6, [6]), following the third growing season at the JKI site in Braunschweig (March 2012). Data from three plots of 50 plants with a planting density of 2 plants $\mathrm{m}^{-2}$, each in a randomised block. The field design is similar to those in [4]. Error bar $=+/-1 \mathrm{SE}$.

\section{Tracks 3 and 4: Improvement through Hybridisation}

Twenty-six informative microsatellite DNA simple sequence repeat (SSR) markers developed by CERES Inc. (Thousand Oaks, CA) were used to categorize 240 genotypes in a trial planted in 2005 in Aberystwyth into eight molecular diversity groups. These genotypes showed a wide diversity in flowering times from late June to October, and some genotypes never flowered. To achieve the flowering synchronization needed to test hybridization between diverse genotypes, a range of treatments were used including: (i) delaying spring growth in winter state plants by keeping rhizome at $\sim 4{ }^{\circ} \mathrm{C}$, i.e., lower than the threshold for regrowth; (ii) removing physiologically older stems to stimulate younger 'shorter' shoots into maturity; and (iii) using climate controlled environments to precisely control and vary the progression of photoperiod. The latter was the most successful and bagged crosses of several thousand cross combinations were made over a period of five years. These bi-parental crosses were made in every SSR grouping and demonstrated that there was no genetic interspecies barrier (Figure 4).

Figure 4 shows a matrix approach to investigate the crossing compatibility across 240 diverse genotypes. This visualization was automated in our bespoke MSQL breeding database we called "MSCAN". Each time a cross was attempted and recorded on MSCAN, a red 'dot' appeared. When the cross was found to have produced seed, the dot was changed to blue. This dynamic near real-time visualization allowed those making the crosses to see where further crosses should be attempted to explore the available genotypic diversity. In addition to biparental crosses, single panicles were also bagged to test if any of the genotypes were capable of producing 'self' pollinated seed. Careful examination of the 1:1 diagonal line in Figure 4 shows that a few genotypes tested appeared to be self-compatible and produced seed that germinated. These tests for selfs, while a useful screen, depend on the quality of pollination control by the materials used to create the crossing bags and were not further investigated using markers, but provide an indication of the potential to identify self-compatible Miscanthus. 


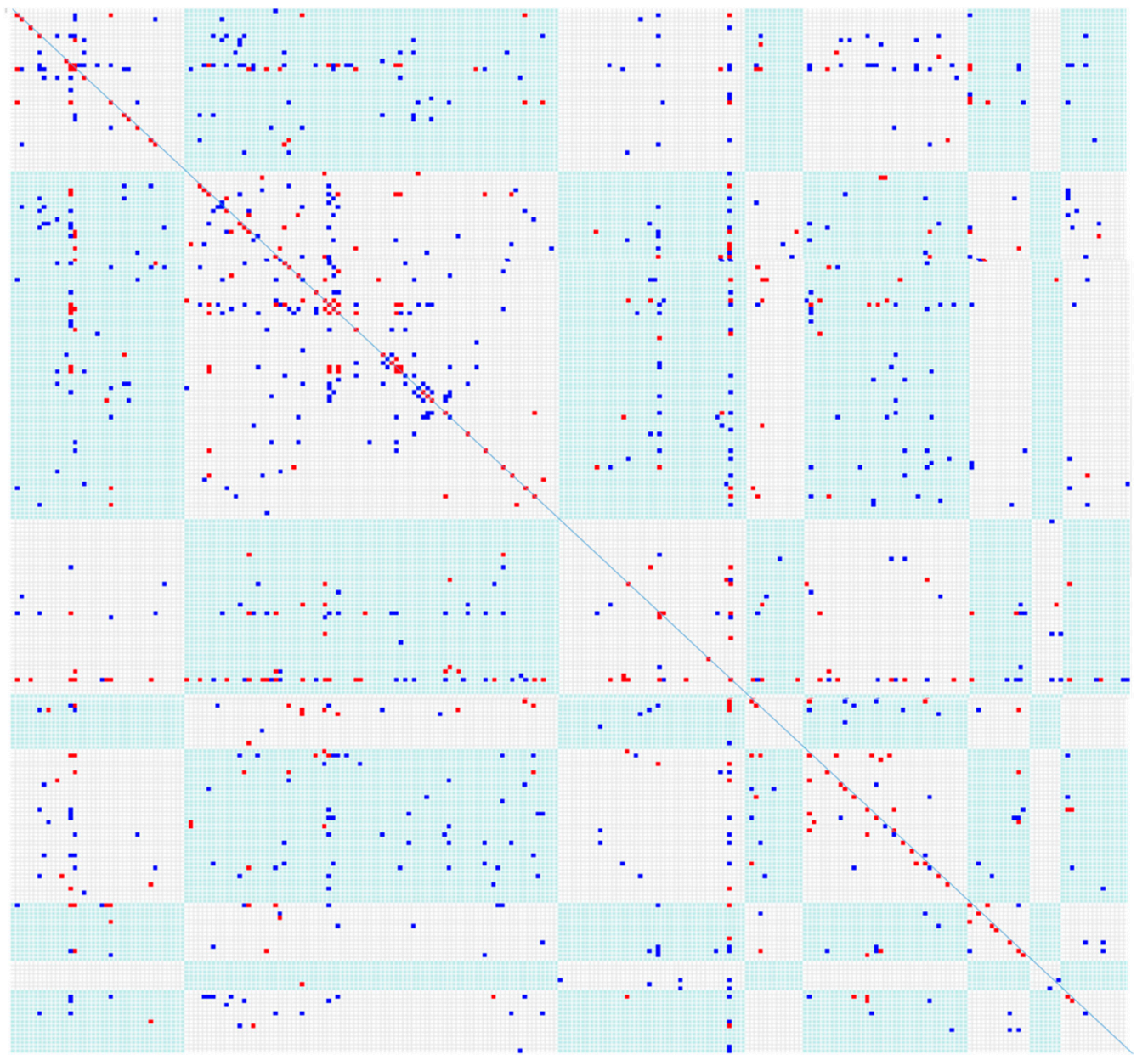

Figure 4. Each row and column represent 240 Miscanthus genotypes, sourced from European collections. These were sorted into 8 phylogenetic groups distinguished by microsatellite DNA simple sequence repeats (SSRs) across the $x$-axis (seed bearing) and $y$-axis (pollen donor) by the background of alternating light blue and white. Each colored dot represents a cross or a selfing attempt: red for attempted but unsuccessful, blue for successful i.e., the cross produced progeny. Pollination control was achieved by bagging two panicles, one from each parent in pollen proof bags. The diagonal 1:1 line are self-pollinations made by bagging single panicles.

All glasshouse crosses were performed with a mixture of traditional glassine paper and modern non-woven fabric bags. Glassine is light and convenient to use, but is a delicate paper susceptible to physical damage. Crossing bags made from non-woven polyester fibers were more breathable and overall gave a higher seed set than glassine bags [20]; however, polyester bags were heavier and needed to be supported, which greatly added to the time taken to set up crosses. Detailed investigations of the environment effects of different materials used for crossing bags showed very complex interactions: higher light transmission produced high within bag temperatures, especially in glassine paper [21]. Thus, we found the immediate crossing environment, over and above genetic compatibility and flowering synchronization, contributed to the success or failure of the crossing attempt. Therefore the crosses in Figure 4 are indicative, rather than an absolute test of genotypic compatibility. Interestingly, controlling these extra environmental factors clearly showed that crosses could be achieved between all groups in the diversity matrix and in a very small number selfed seed were possible. Overall, we consider the ability to self a negative trait, since the breeding strategies based on F1 hybrids rely on self-incompatibility.

In general, seed from crosses made in autumn were sown in sand and transferred to modular plugs in January/February. Between 2007 and 2012, the plugs were space-planted into nurseries at 
Aberystwyth and Braunschweig in May, after the risk of late spring frosts was reduced. Plant losses upon transplanting to the field in Aberystwyth were invariably higher than those in Braunschweig. The combination of low temperatures, marginal land with low soil $\mathrm{pH}$ and competition from native grass weeds resulted in high risk, slow establishment with plants typically no taller than $75 \mathrm{~cm}$ in autumn. In contrast, warmer summer temperatures and light textured soils in Braunschweig resulted in rapid establishment. Low continental winter temperatures in Braunschweig meant established plants could be screened for cold tolerance of the overwintering rhizomes. The Braunschweig site, in the middle of Europe, turned out to be strategically the right place to make first stage selections for track 4 because the rankings based on phenotypes were consistent with other 'slower selection' locations in Europe. Using the Braunschweig site enabled selections of vigorous hybrids to be made after two years that could be promoted to the next phase: multi-location plot trials.

\section{Phenotyping in Multi-Location Plot Trials}

In 2011, a European project 'Optimising Miscanthus, OPTIMISC' provided an opportunity to appraise $\mathrm{G} \times \mathrm{E}$ interactions with both wild and genetically improved Miscanthus planted at six locations across a wide climatic range; from cold sites such as Moscow in Russia, warm sites such as Adana in Turkey to mild and high rainfall sites such as Aberystwyth in Wales [22]. Promising clonal wild accessions from Track 2 (nurseries) and some hybrids from Track 4 that looked promising at the end of the first growing season in Braunschweig were selected to be part of the OPTIMISC trial. The capacity to clone plants in vitro and raise sufficient plug plants for replicated plot trials at six OPTIMISC locations in 2012, limited plot sizes to 50 plants at 2 plants $\mathrm{m}^{-2}\left(25 \mathrm{~m}^{2}\right)$. These trials showed different morphotypes were largely not specified by environment and that a high performing genotype in one site was mostly high performing across all sites. This may have been because the site of selection in Braunschweig, Germany represented a reasonable amalgam of the extremes of cold and drought experienced across the other diverse Continental European sites. It is difficult to extend this kind of large-scale empirical analysis to more sites, which is where the modelling of yield is important. A growth model was developed and refined that takes meteorological and soil data as input and estimates yield at a spatial resolution of $1 \mathrm{ha}$. This model was largely developed and parameterised with data from field trials growing $M \times g$. Controlled environments and field experiments have demonstrated that $M \times g$ is sensitive to drought stress in particular, but also chilling stress and that accessions that yield more under abiotic stress have been identified $[23,24]$. Thus there is identified genetic potential for improvements over the current commercial standard in particular stressed environments. The impacts of abiotic stress such as drought, cold and salinity on the available area of economic cultivation has been modelled [25] and parameters modified to illustrate the potential gains from adding the improved performance of new accessions to $M \times g$ [12]. Important in the political context of gaining support for breeding energy crops spatial models for yield have been extended to identify the particular geographical areas best suited to production at low carbon intensity to produce a more sustainable energy efficient crop ([2], Figure 1).

Five years later, production systems for seeded hybrids had developed at such a pace using developments from the GIANT (Genetic Improvement of Miscanthus as a sustainable feedstock for bioenergy in the UK, 2011-2016) and MUST (Miscanthus Up-Scaling Technology, 2016-2019) projects, that in 2018 multi-location trials at plot ( 0.8 ha per site) and field scales ( 3.6 ha per site) were achievable in the EU project GRACE (Growing advanced industrial crops on marginal lands for biorefineries, 2017-2022).

Standardized phenotyping protocols are needed to compare traits between hybrids within sites, between years, across sites and across different projects. In practice, phenotyping is dependent on the resources, experience and commitment of the teams running the trials. The term schema is used in MSQL and phenotyping schemas were used to standardize protocols. To help those gathering and analyzing the data our system used schema names that were 'human readable' and used a 'CamelText' format followed by the units of measurement e.g.,_cm (centimetres). In Table 1, phenotyping schemas 
for a set of 'growth phenotypes' have been arranged in chronological order starting from trial planting through to maturity. The appropriate phenotypic measurements adjust slightly as the crop matures. The main reason to collect a phenotype is given in the 'use' column. Some phenotypic measurements are made at one or more measurement levels: plant/plot/quadrat. In large field scale trials of several hectares, such as used in the OPTIMISC and GRACE projects, phenotypes used 'notional' quadrats (could be patches of rows and columns) positioned appropriately to satisfy random sampling to obtain a representative sample. Protocol details were difficult to communicate across languages and cultures and 'in field' training backed up by protocol videos were found to be an effective means to standardize methods. When and what phenotypes were measured depended on the aims of the particular project, the available resources and crop age. Some measurements were considered essential and in tables these are marked 'mandatory'. These include an assessment of plant losses (gaps) caused mainly by death at transplanting or winter freezing or late frosts after leaf emergence from the overwintering rhizomes in spring. Other traits considered mandatory have a minimum data collection frequency, where more measurements are encouraged. For example, canopy height made at plot level is a simple informative phenotype, but when made regularly it can be used to derive parameterized equations to identify interactions between seasonal growth dynamics and the changing environment [26]. The alignment of these processes with meteorological data underlies the calibration of process descriptions needed to tailor crop models to specific hybrids and thereby improve predictions of crop performance across different countries.

In Europe, biomass harvests are generally performed in late winter/early spring because delaying harvest reduces moisture, nutrient and ash contents. However, there are combinations of hybrid $x$ environment $x$ end use applications where earlier harvests are performed before winter senescence [27]. Table 2 shows the schemas for yield determination at harvest. To make harvest assessments small forage harvest machines developed for maize were found to be ideal, but if not available quadrat harvests taken with hedge cutters was a method that was readily standardized across sites. The optimum area for quadrats depended on the plot size and crop morphology. A study in Germany showed yield estimates from quadrats of less than $4 \mathrm{~m}^{2}$ could not be reliably scaled to $\mathrm{Mg} \mathrm{DM} \mathrm{ha}^{-1}$ [28]. Generally, harvest quadrats performed for scientific studies of Miscanthus plots were 6-12 $\mathrm{m}^{2}$. The quality of the harvest data depended on accurate weighing of the fresh weight of all the biomass in the quadrat (FWQuadrat_kg) and of the subsamples (FWSS and DWSS). Large variations ( $>10 \%)$ in moisture contents within a hybrid, were found to be an indication of low data quality. Particular attention needed to be applied to sources of common errors, mostly due to sub-sample handling between the field and the laboratory where the samples were processed and oven dried. Table 2 provides a list of mandatory and optional harvest-related phenotypes commonly used to assess differences between hybrids and locations. In our experience the splitting of subsamples into leaf and stems, while informative to understand the contribution to high ash contents of the leaf fraction, is often a poor return on investment in early stage trials or young crops. We have concluded that it is better to have a phased approach to the selection process, before leaf stem separations are attempted on a few targeted selections. 
Table 1. Phenotyping schema names and protocols developed for Miscanthus

\begin{tabular}{|c|c|c|c|c|}
\hline Phenotyping Schema Name & Use & Measurement Level & Protocol & When Performed \\
\hline SurvivingPlants_pc & $\begin{array}{l}\text { To compare establishment and overwintering } \\
\text { survival. }\end{array}$ & plot/quadrat & $\begin{array}{l}100 \times \text { Surviving plant count divided by } \\
\text { planted plants. }\end{array}$ & $\begin{array}{l}\text { July after planting and October (year } \\
\text { 1) and following June (year 2) }\end{array}$ \\
\hline EHeight_cm & $\begin{array}{l}\text { Used to accurately calculate the start of } \\
\text { growth. }\end{array}$ & plant & $\begin{array}{l}\text { Measure from first emergence, from soil } \\
\text { level to shoot tip/leaf tip. }\end{array}$ & $\begin{array}{l}\text { Weekly March to May (until longest } \\
\text { shoot is }>40 \mathrm{~cm} \text { ). }\end{array}$ \\
\hline FrostDamagePlantParts_0-9 & $\begin{array}{l}\text { To assess leaf/canopy damage by frosts } \\
\text { occurring after spring emergence. }\end{array}$ & plant & $\begin{array}{l}0-9 \text { scale of damage to plant part e.g. leaf } \\
\text { where } 0 \text { is undamaged. }\end{array}$ & Weekly March to June. \\
\hline $\begin{array}{l}\text { FrostDamage } \\
\text { PlantsinPlot_pc }\end{array}$ & $\begin{array}{l}\text { No. of plants with score of } 8 \text {, based on above } \\
\text { frost score, to assess season start and stop. }\end{array}$ & plot & $\begin{array}{l}\text { Using quadrat of } 16 \text { plants with } 7 \text { plants } \\
\text { affected; } 100 \times 7 / 16=44 \%\end{array}$ & Weekly March to June. \\
\hline CanopyHeight_cm & $\begin{array}{l}\text { To compare morphology and create growth } \\
\text { curves for models. }\end{array}$ & $\begin{array}{l}\text { plant/plot/ } \\
\text { quadrat }\end{array}$ & $\begin{array}{l}\text { From ground to where most of the leaves } \\
\text { bend to create a canopy. }\end{array}$ & $\begin{array}{l}\text { Monthly, or higher frequency if } \\
\text { resources allow. }\end{array}$ \\
\hline $\begin{array}{l}\text { TotalStems_ } \\
\text { countperplant }\end{array}$ & $\begin{array}{l}\text { To compare plant morphologies contributing } \\
\text { to yield \& quality. }\end{array}$ & plant & Count all stems over $10 \mathrm{~cm}$. & Late autumn (normally October) \\
\hline BigStems_countperplant & $\begin{array}{l}\text { To compare plant morphologies making } \\
\text { yield and quality. }\end{array}$ & plant & $\begin{array}{l}\text { Count the number of stems which reach } \\
60 \% \text { of the CanopyHeight. For spreading } \\
\text { plants count within } 0.5 \mathrm{~m}^{2} \text { (use a frame of } \\
71 \times 71 \mathrm{~cm} \text { ). }\end{array}$ & Late autumn (normally October) \\
\hline Greenness_0-9 & $\begin{array}{l}\text { To compare senescence from drought, cold } \\
\text { and nutrient deficiency. This helps interpret } \\
G \times \text { E effects. }\end{array}$ & $\begin{array}{l}\text { plant/plot/ } \\
\text { quadrat }\end{array}$ & $\begin{array}{l}\text { Visual score where } 9=\text { all leaves dark green, } \\
5=\text { half of canopy green, } 1=\text { totally brown. }\end{array}$ & $\begin{array}{l}\text { When environmental stress events } \\
\text { result in differences. } \\
\text { At least in late autumn and again just } \\
\text { before spring harvest. }\end{array}$ \\
\hline FloweringScore_0-5 & $\begin{array}{l}\text { This visual score helps identify the window } \\
\text { of flowering to understand cross pollination } \\
\text { possibilities of different hybrids, resultant } \\
\text { seed set, shattering and establishment of } \\
\text { volunteer seedlings. }\end{array}$ & $\begin{array}{l}\text { plant/plot/ } \\
\text { quadrat }\end{array}$ & $\begin{array}{l}\text { Flowering Score (FS) } \\
\text { 0-no flowering } \\
\text { 1-Flag leaf visible } \\
\text { 2-Panicle }>1 \mathrm{~cm} \\
\text { 3-Start of anthesis (yellow anthers) } \\
\text { 4-Main flowering period (flowering } \\
\text { intensity }>=50 \% \text { of 'big' stems that } \\
\text { contribute to the canopy) } \\
\text { 5-Flowering complete (no anthesis on any } \\
\text { stems). }\end{array}$ & $\begin{array}{l}\text { Monthly from July and at higher } \\
\text { frequencies once flowering has } \\
\text { begun. }\end{array}$ \\
\hline $\begin{array}{l}\text { PlantBasal } \\
\text { Diameter_cm }\end{array}$ & $\begin{array}{l}\text { To assess plant maturity and or a measure of } \\
\text { potential for invasion by rhizome creep. }\end{array}$ & plant & The diameter of the 'tuft' at plant base. & $\begin{array}{c}\text { Late autumn, or just after spring } \\
\text { harvest. }\end{array}$ \\
\hline $\begin{array}{l}\text { PanicleHeight_ } \\
\mathrm{cm}\end{array}$ & To understand morphological differences. & $\begin{array}{l}\text { plant/plot/ } \\
\text { quadrat }\end{array}$ & $\begin{array}{l}\text { The height from the ground to the base of } \\
\text { the panicle of the tallest flowering stem. }\end{array}$ & $\begin{array}{l}\text { Late autumn when growth has } \\
\text { ceased. }\end{array}$ \\
\hline $\begin{array}{l}\text { Light } \\
\text { Interception_pc }\end{array}$ & $\begin{array}{l}\text { Assessing when and to what extend the leaf } \\
\text { canopy is intercepting available incident } \\
\text { light. }\end{array}$ & plot/quadrat & $\begin{array}{l}\text { The light intercepted by the canopy as } \\
\text { measured by a 'line ceptometer'. } 0 \% \text { no } \\
\text { interception. }>95 \% \text { full canopy closure. }\end{array}$ & March to October. \\
\hline
\end{tabular}


Table 2. Schemas for parameters used to quantify dry matter yield at harvest from subsampling.

\begin{tabular}{|c|c|c|}
\hline Phenotyping Schema Name & Use & Protocol \\
\hline QuadratArea_m2 & $\begin{array}{l}\text { Yield assessments are based on sampling area - here called a } \\
\text { 'QuadratArea'. }\end{array}$ & $\begin{array}{l}\text { Minimum sample area for Miscanthus is } 6 \mathrm{~m}^{2} \text {. In practice quadrats may not be } \\
\text { used and the harvested area is calculated from the number of rows and columns } \\
\text { of plants harvested in a plot and the plant density. }\end{array}$ \\
\hline $\begin{array}{l}\text { FWQuadrat } \\
\quad \text { kg }\end{array}$ & Bulk 'fresh weight' from the 'QuadratArea_m2' harvested. & $\begin{array}{l}\text { The fresh weight in } \mathrm{kg} \text { of the stems cut within the QuadratArea_m2 at a cutting } \\
\text { height of } 5 \mathrm{~cm} \text { above ground level. Often measured immediately 'on field' using } \\
\text { a tripod and hanging balance method. }\end{array}$ \\
\hline FWSS_g & $\begin{array}{l}\text { Fresh Weight of a subsample to calculate the moisture content } \\
\text { and dry matter yield; samples may be used for compositional } \\
\text { analysis. }\end{array}$ & $\begin{array}{l}\text { A typical subsample is } \sim 200 \mathrm{~g} \text { fresh weight of randomly selected whole stems, } \\
\text { or from well mixed chip. FWSS_g should be determined as quickly as possible } \\
\text { after the FWQuadrat_kg to avoid moisture losses. }\end{array}$ \\
\hline $\begin{array}{l}\text { Moisture } \\
\text { Content_pc }\end{array}$ & MoistureContent_pc is a key biomass quality characteristic. & $=100 \times($ FWSS_g - DWSS_g $) /$ FWSS_g. \\
\hline $\begin{array}{l}\text { QuadratDW } \\
\quad k g\end{array}$ & $\begin{array}{l}\text { QuadratDW_kg is an intermediate in upscaling measurement } \\
\text { of yield. }\end{array}$ & $=$ FWQuadrat_kg - FWQuadrat_kg $\times($ MoistureContent_pc/100) \\
\hline Yield_tDWperha & Expressed as tonnes dry matter per ha, or in SI units ' $\mathrm{Mg} \mathrm{ha}^{-1}$ '. & $=(10,000 /$ QuadratArea_m2 $\times$ QuadratDW_kg $) / 1000$ \\
\hline FWLeafSS_g & Improves yield assessment by calculating 'leaf share'. & $\begin{array}{l}\text { Quantify leaf lamina, not leaf sheath which is difficult to separate from the } \\
\text { stems. Should be determined as quickly as possible after the FWQuadrat_kg. }\end{array}$ \\
\hline DWLeafSS_g & Improves yield assessment by calculating 'leaf share'. & $\begin{array}{l}\text { FWLeafSS is dried to constant weight at } 105^{\circ} \mathrm{C} .40-60^{\circ} \mathrm{C} \text { may be used if } \\
\text { carbohydrate analysis is required. }\end{array}$ \\
\hline $\begin{array}{l}\text { MoistureContent } \\
\text { Leaf_pc }\end{array}$ & A key biomass quality characteristic. & $=100 \times($ FWLeafSS_g - DWLeafSS_g $) /$ FWLeafSS_g. \\
\hline FWStemSS_g & To assess proportion of yield due to stem. & $\begin{array}{l}\text { Includes stems (culm) and leaf sheath; measured as soon as possible after the } \\
\text { FWQuadrat_kg to increase accuracy of moisture content data. }\end{array}$ \\
\hline DWStemSS_g & To assess proportion of yield due to stem. & $\begin{array}{l}\text { The FWStemSS is dried to constant weight at temperatures } 105^{\circ} \mathrm{C} .40-60^{\circ} \mathrm{C} \text { is } \\
\text { recommended for analysis of cell wall carbohydrates (lignin and cellulose). }\end{array}$ \\
\hline $\begin{array}{l}\text { MoistureContent } \\
\text { Stem_pc }\end{array}$ & To assess proportion of yield due to stem. & $=100 \times($ FWStemSS_g - DWStemSS_g $) /$ FWStemSS_g \\
\hline $\begin{array}{l}\text { LeafBiomass } \\
\text { Proportion_pc }\end{array}$ & To assess proportion of yield due to leaf. & $=100 \times($ DWLeafSS_g $/($ DWLeafSS_g + DWStemSS_g $))$ \\
\hline $\begin{array}{l}\text { StemBiomass } \\
\text { Proportion_pc }\end{array}$ & To assess proportion of yield due to stem. & $=100^{*}($ DWStemSS_g $/($ DWLeafSS_g + DWStemSS_g $))$ \\
\hline $\begin{array}{l}\text { StemBasal } \\
\text { Diameter_mm }\end{array}$ & $\begin{array}{l}\text { Impacts senescence rate and moisture content, harvesting and } \\
\text { baling efficiency. }\end{array}$ & Measure the basal diameter of $\sim$ five randomly selected stems. \\
\hline $\begin{array}{l}\text { StemWallAt } \\
\text { Base_mm }\end{array}$ & $\begin{array}{l}\text { Impacts senescence rate and moisture content, harvesting and } \\
\text { baling efficiency. }\end{array}$ & Measure at base of $\sim$ five randomly selected stems. \\
\hline
\end{tabular}

Units:_pc = percent;_mm=millimeter;_cm = centimeter;_g = grams;_tDWperha = Mg dry weight per hectare. 


\section{Selection Criteria and Methodology}

The phenotyping described above was used to quantify performance attributes of progeny from crosses along a phased screening chain illustrated in Figure 5. These are the hurdles that progeny must clear in a long race to become a winning hybrid and commercial variety. The first phase is early plant development and survival. Miscanthus has small seed, high germination temperatures and slow initial rates of growth following germination [29]. Therefore, before transfer to the field environment, growth in small compost plugs is the current standard method used to establish Miscanthus seedlings.

\section{Nurseries and Small plot trials}

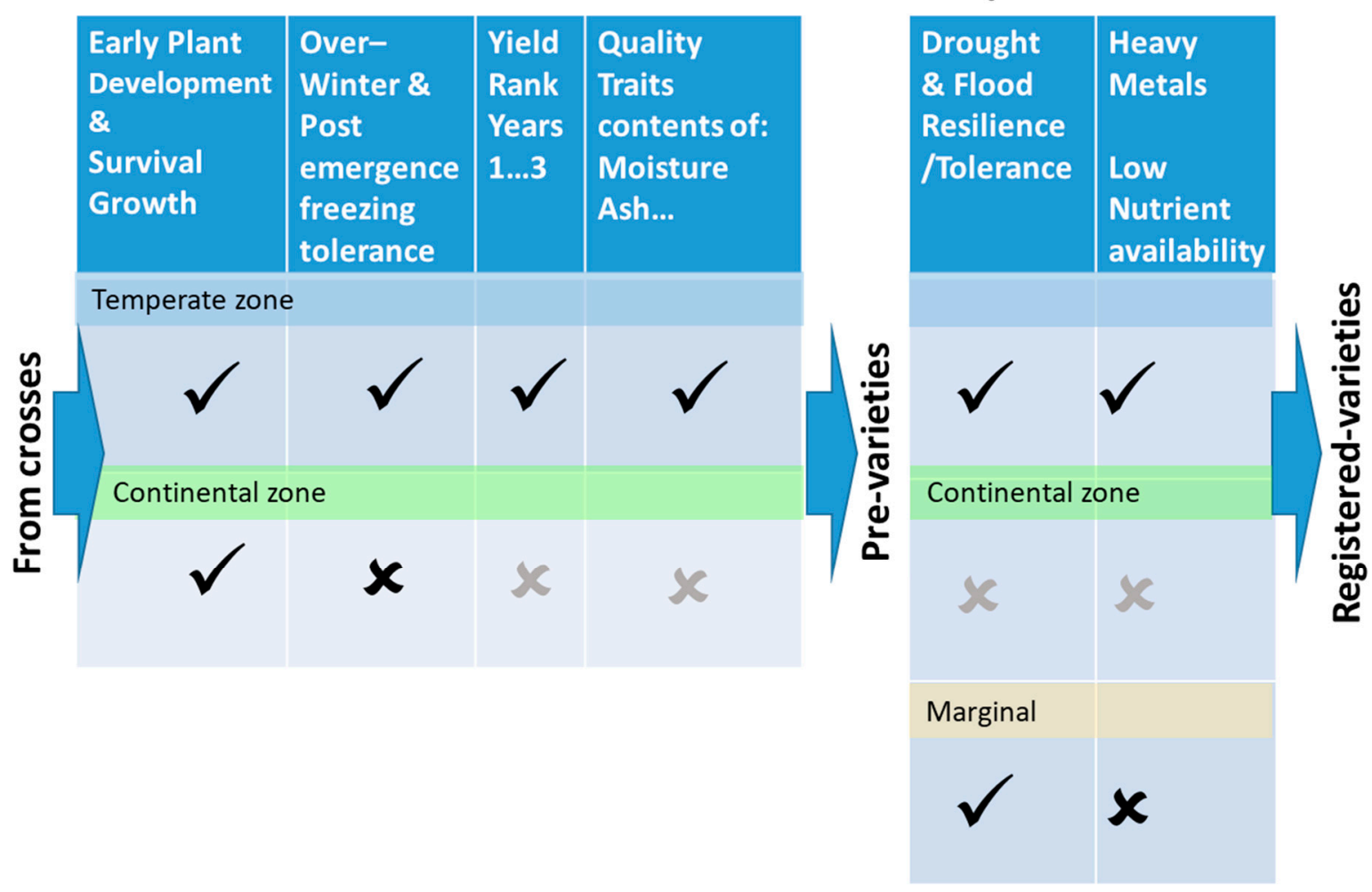

Figure 5. A schematic showing the different phases of selection applied to the progeny of crosses from successful transplantation, sufficient first season growth to overwinter through to the production of biomass yields above $10 \mathrm{t}$ by the end of the second year with low ash and moisture content. Once a fail (an ' $X$ ') occurs in the selection sequence, the hybrid is eliminated. The extra steps indicated for pre-varieties illustrates further resilience testing related to likely stresses encountered on marginal lands. The resilience tests include tolerance to flooding, drought, low nutrients and heavy metal contaminants in the soil and apply to both potential parents and progeny.

The counts of surviving plants to derive 'SurvivingPlants_pc' (Table 1), were performed at about six weeks after planting, and again at the end of the growing season. There are many reasons why plug plants may fail to establish, including immature or unhardened seedlings, poor plug to soil contact and prolonged drought, grazing and weed competition. We have found that most of these establishment risks can be managed by covering the plants immediately after transplanting with a thin mulch film which degrades after 6-8 weeks. These mulch films prevent moisture loss and increase the growth rates by raising the soil temperatures about $4{ }^{\circ} \mathrm{C}$ [29]. Film coverings also protect the crop from grazing hares/rabbits, bird damage and late frosts but may stimulate weed growth and there are concerns over microplastics entering the soil. Solutions to both these problems are being actively researched in the current GRACE project by using bio-herbicides and biomass-derived biodegradable films. In our 
experience, the risk reduction and acceleration in establishment from the use of film outweighs its economic cost. Any establishment problems are compounded in later years.

An adequate first year growth rate is needed to reach a level of physiological maturity to produce sufficient rhizome growth to maximise the likelihood that the plant will survive over winter. Young plants have small amounts of immature and shallow rhizome making them more susceptible to sub-zero soil temperatures than older plants. By phenotyping in October, including a further plant count, plant losses within the growth season and during winter can be distinguished. Rapid above ground measurements of canopy height (CanopyHeight_cm) and stem counts per plant (BigStems_countperplant) were normally used to assess early plant development and maturity before winter, but occasionally onerous estimates of the below ground biomass and freezing tests have been made in Miscanthus [30]. Sometimes fast growing hybrids died during the first winter in Braunschweig, and it was noted that this often coincided with a lack of autumn senescence. Successful overwintering is crucial, but a standardized field treatment, to test overwintering, is practically unattainable because the depth and timing of subzero temperatures and soil moisture varies from year to year. Braunschweig's continental climate was reasonably consistent and trials there were successful in identifying resilient germplasm in 2010/11 for the OPTIMISC multi-location trials which included cold winter sites in Ukraine and Moscow. However, plants making it through to the second year in Braunschweig were not guaranteed cold tolerant for locations and years with exceptionally severe winters.

Once plants survived the first winter, the rate of plant development depended on growing conditions and interactions between hybrid, temperature, water availability and soil texture. On light sandy soils, in warm locations mature maximal yields were reached by the end of the second year. However, on heavy clay soils and cool climates, Miscanthus may require up to 5 years to reach mature yields. Pragmatically we have used an assessment of yield after two years in nurseries before promotion to replicated multi-location plot trials. There are so many longer term factors that could impact yield but are difficult to include in a breeding programme, such as the effects of initial planting densities on long term yields. Long-term trials are essential for environmental and economic analyses, and these at present rely on a few long term yield series from $M \times g$. However, longer term trials with more diverse high yielding germplasm will be needed to mitigate against potential problems not encountered within short term screening programmes.

The screening of novel germplasm and different breeding tracks (Figure 1), the extensive hybrid crossing programme (Figure 4) and phenotyping across sequential selection criteria (Tables 1 and 2 and Figure 5) used in the breeding programme led from Aberystwyth has identified new competitive Miscanthus hybrids. Figure 6 shows a side by side comparison of one such new clonal hybrid, GNT-10 and the commercial standard $M \times g$, planted in replicated plot trials in Lincoln (UK) and in Poznan (Poland) in 2014. In Lincoln, during the second and third growing seasons rainfall patterns ensured growth without water deficit and $M \times g$ performed as expected reaching $\sim 10 \mathrm{Mg} \mathrm{DM} \mathrm{ha}^{-1}$, while GNT-10 out-yielded $M \times g$ by almost one third. Meanwhile at a site near Poznan on a light sandy soil long drought periods occurred during mid-growing season in both the second and third years. The calculated soil moisture deficits in Poznan reached $<200 \mathrm{~mm}$ for 6-8 weeks, way below estimated plant available water capacity of $70 \mathrm{~mm}$ in the soil profile exerting a strong drought. Under the drought prone conditions at the site in Poznan growth of $M \times g$ was severely restricted producing only $\sim 2 \mathrm{Mg} \mathrm{DM} \mathrm{ha}^{-1}$, five times less than GNT-10 which produced $\sim 11 \mathrm{Mg} \mathrm{DM} \mathrm{ha}^{-1}$. 


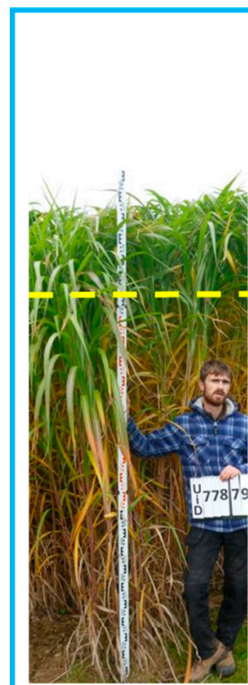

Mxg

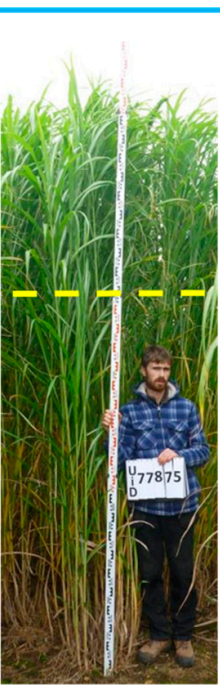

GNT-10

\section{Lincoln, UK} 'Wet site'

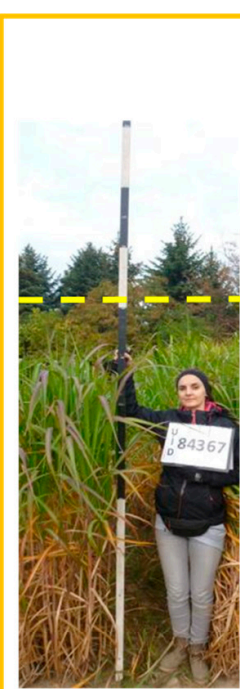

$M \times g$

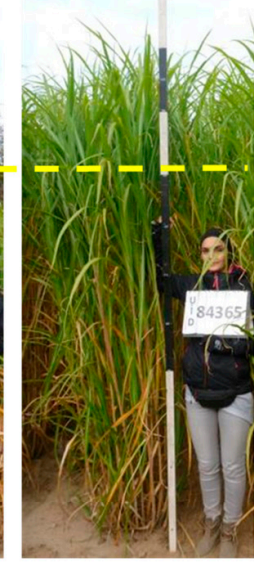

GNT-10

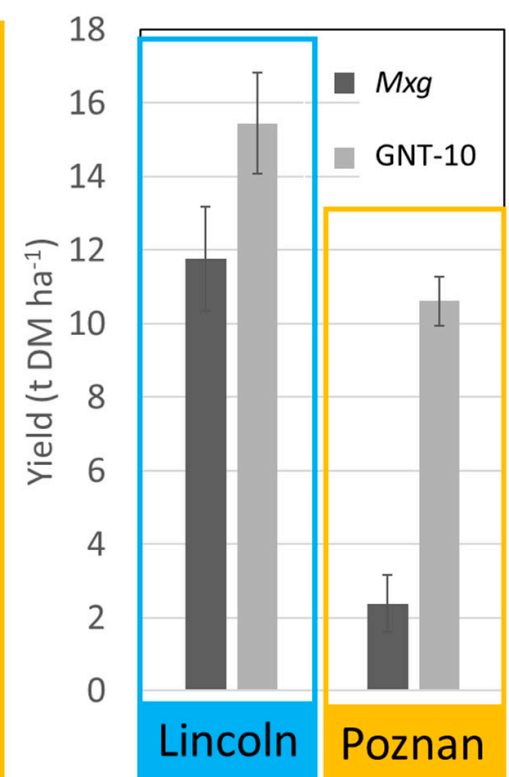

$$
\begin{aligned}
& \text { Poznan, PL } \\
& \text { 'Dry site' }
\end{aligned}
$$

Figure 6. A side by side comparison of average yield in years two and three combined for a novel clonal hybrid 'GNT-10', from the breeding programme at Aberystwyth, and the commercial standard $M \times g$. Plants were grown in replicated plot trials in Poznan (Poland) and in Lincoln (UK), photos are of the second (PL) and third (UK) years following planting respectively. In Poznan, there were long drought periods with soil moisture deficits below $200 \mathrm{~mm}$ for several weeks in the growing seasons, the resulting growth in $M \times g$ was severely restricted. In Lincoln, there was adequate water supply and $M \times g$ performed as expected but was still out-yielded by GNT-10. A yellow dotted line shows $2 \mathrm{~m}$ above ground level. Error bar = +/ $1 \mathrm{SE}$.

Such large differences in productivity, particularly when water is limited, are game changers, especially when considering cultivating biomass crops on marginal land to achieve carbon sequestration, phyto-remediation, soil stabilization, and providing new business opportunities for rural economies. A recent EU project entited 'Miscomar' (Miscanthus for contaminated and marginal land) showed that novel Miscanthus hybrids, with similar water conservation traits to GNT-10, when grown on metal contaminated land excluded heavy metals over a period of three years [31] suggesting Miscanthus could be used to bring contaminated land back in to useful production. The approach taken thus far in domesticating Miscanthus reflects the early days of domesticating a crop that had attracted relatively little research funding. The perennial nature and complex genome are challenges for phenotyping and genetic analysis. The performance of a natural wide hybrid suggested potential gains were possible from wild accessions but this was not realised from the collections made. To make progress pragmatic decisions were made including to "cross the best with the best". Markers and conventional cyclical species improvement programmes are being developed but from such an initial paucity of information the generation of multiple interspecific hybridisations generated both potential product and information about which species might be most successful parents.

\section{Conclusions and Future Improvements in Miscanthus Breeding}

Biomass yield has been a particular focus for improvement; however, Miscanthus is a relatively undomesticated crop and there are potentially many traits that could be optimised [16]. Many trials have shown Miscanthus is well adapted to regions where it is non-indigenous. There are concerns that fertile Miscanthus hybrids could become an invasive weed in lower latitude warmer climates 
that stimulate flowering where the risk of seed shatter a volunteer establishment is higher. Although field trials performed to date indicate the risk is quite low, breeding sterile triploid hybrids would virtually eliminate invasive risk by seed, and could help speed up the adoption of Miscanthus by policy makers and growers. Manipulating ploidy or improvements to triploid germplasm using transgenic manipulation also represent possible routes to develop future improvements. Miscanthus has proven comparatively recalcitrant to tissue culture in our experiments at Aberystwyth; however, others have reported success at generating synthetic polyploids [32] and in generating stable transformants [33].

The speed of breeding programmes obviously affects economic cost but, imperative to biomass crops in particular, speed also affects the potential global impacts that such crops can make in the current climate emergency. We attempted to increase the speed of selection using the Track 1 and Track 2 approaches described above but found that competitive germplasm was generated by using the more conventional but slower breeding schemes. Markers and genomic selection may be used to reduce the length of breeding cycles. A particular challenge to the application of molecular selection is that Miscanthus has a large complex genome including a recent duplication [34] and few available genomic resources. Resources may be adapted from closely related species such as Sorghum [35,36] but the Miscanthus breeding programme at Aberystwyth has developed and tested the potential for de novo molecular resources to impact breeding. A high resolution genetic map including all 19 linkage groups was produced [37] and genome wide association studies highlighted the potential of genomic selection by focusing on 138 genotypes of $M$. sinensis species $[38,39]$. Clark et al. [40] have further demonstrated the potential of this approach using populations phenotyped at different sites. We have recently demonstrated the potential of genomic prediction and index selection to optimise selection across multiple target traits in Miscanthus [41]. The power of predictive models may be improved when more individuals are included and our early studies are being extended across larger populations in excess of 800 genotypes from the collections at Aberystwyth.

In conclusion, the breeding foundations have been laid well for Miscanthus over the long time periods necessary with the combination of public and private funding. The upscaling of improved seed-based hybrids is ongoing, and technical solutions are being found for every known barrier. These hybrids can be commercially scaled up over a few years if real, stable market opportunities emerge in response to sustained favourable policies. The contributions of growing and using Miscanthus for socioeconomic and environmental benefits are clear on paper, but in practice these are still being worked out with regionally diverse actors along the biomass value chains. While innovations in the GRACE project focus on Europe, the opportunity for biomass value chains span large areas globally, including countries in Sub-Saharan Africa, China and the Americas. The large-scale deployment of Miscanthus in all these areas needs developments outside the breeding arenas, but we feel confident that our experience and the resources developed over the past 15 years of working with Miscanthus will allow us to develop a globally impactful biomass crop.

Author Contributions: J.C.-B. and P.R. led the writing, drawing on unpublished work from over 15 years, from the co-authors listed below: D.A.-C., A.I., C.H., R.S. and S.Y., C.R., J.G., D.S. and S.C. performed or facilitated glasshouse and field crosses. K.-U.S., H.M. and J.G. ran the Braunschweig selection site. M.M. (while at Aberystwyth (PhD), Blankney Estates and Terravesta Ltd.) and C.A. led the field evaluations. L.H., J.N., M.S. and T.S. developed the genomic and informatics. R.F. and I.D. guided the programme.

Funding: The breeding was mainly supported by the Biotechnology and Biological Sciences Research Council (BBSRC), Department for Environment, Food and Rural Affairs (Defra), the BBSRC CSP strategic funding grant BB/CSP1730/1, Innovate UK/BBSRC 'MUST' (Miscanthus Up-Scaling Technology, 2016-2019) BB/N016149/1, CERES Inc., Terravesta Ltd. and Blankney Estates, through the GIANT-LINK project (LK0863). Genomic selection and Genome-wide association study activities were supported by BBSRC grant BB/K01711X/1, the BBSRC strategic programme grant on Energy Grasses \& Bio-refining BBS/E/W/10963A01. EU projects OPTIMISC (Optimising Miscanthus Biomass Production, 2012-2016) and GRACE (Growing advanced industrial crops on marginal lands for biorefineries, 2017-2022) supported multi-location trial networks.

Acknowledgments: Andreas Kiesel, Moritz Wagner and Elena Magenau (University of Hohenheim) helped J.C-B develop the latest version of the phenotyping protocols presented in Tables 1 and 2 for use in the GRACE project. The individual contributions of William Cracroft-Eley, George Robinson and Sam Buckby (Terravesta 
Ltd.), Jonathan Scurlock (NFU), Susan Weatherstone (EON, now Uniper) and the late Graham Harding (Blankney Estates, UK) are acknowledged.

Conflicts of Interest: "The private sponsors had a significant role in the design of the breeding strategies reported in this manuscript. However, these inputs have not influenced the interpretation of data presented; in the writing of the manuscript, and in the decision to publish the results". The contributing authors include private sector employees.

\section{References}

1. Henderson, G.; Shah, N.; Azapagic, A.; Beerling, D.; Cheeseman, C.; Hepburn, C.; House, J.I.; Le Quéré, C.; Markusson, N.; Shepherd, J.; et al. Greenhouse Gas Removal; The Royal Society and Royal Academy of Engineering: London, UK, 2018; p. 136. Available online: royalsociety.org/greenhouse-gas-removal (accessed on 28 May 2019).

2. Robson, P.; Hastings, A.; Clifton-Brown, J.; McCalmont, J. Chapter 15: Sustainable use of Miscanthus for biofuel. In Achieving Carbon-Negative Bioenergy Systems from Plant Materials; Saffron, E., Ed.; Burleigh Dodds Science Publishing Ltd.: Cambridge, UK, 2019.

3. Stewart, J.R.; Toma, Y.; Fernandez, F.G.; Nishiwaki, A.; Yamada, T.; Bollero, G. The ecology and agronomy of Miscanthus sinensis, a species important to bioenergy crop development, in its native range in Japan: A review. Glob. Chang. Biol. Bioenergy 2009, 1, 126-153. [CrossRef]

4. Kalinina, O.; Nunn, C.; Sanderson, R.; Hastings, A.F.S.; van der Weijde, T.; Ozguven, M.; Tarakanov, I.; Schule, H.; Trindade, L.M.; Dolstra, O.; et al. Extending Miscanthus Cultivation with Novel Germplasm at Six Contrasting Sites. Front. Plant Sci. 2017, 8. [CrossRef]

5. Greef, J.M.; Deuter, M.; Jung, C.; Schondelmaier, J. Genetic diversity of European Miscanthus species revealed by AFLP fingerprinting. Genet. Resour. Crop Evol. 1997, 44, 185-195. [CrossRef]

6. Clifton-Brown, J.C.; Lewandowski, I.; Andersson, B.; Basch, G.; Christian, D.G.; Kjeldsen, J.B.; Jorgensen, U.; Mortensen, J.V.; Riche, A.B.; Schwarz, K.U.; et al. Performance of 15 Miscanthus genotypes at five sites in Europe. Agron. J. 2001, 93, 1013-1019. [CrossRef]

7. Lewandowski, I.; Clifton-Brown, J.C.; Scurlock, J.M.O.; Huisman, W. Miscanthus: European experience with a novel energy crop. Biomass Bioenergy 2000, 19, 209-277. [CrossRef]

8. Heaton, E.A.; Dohleman, F.G.; Miguez, A.F.; Juvik, J.A.; Lozovaya, V.; Widholm, J.; Zabotina, O.A.; Mcisaac, G.F.; David, M.B.; Voigt, T.B.; et al. Miscanthus: A Promising Biomass Crop. Adv. Bot. Res. 2010, 56, 75-137. [CrossRef]

9. Ings, J.; Mur, L.A.J.; Robson, P.R.H.; Bosch, M. Physiological and growth responses to water deficit in the bioenergy crop Miscanthus x giganteus. Front. Plant Sci. 2013, 4. [CrossRef]

10. Clifton-Brown, J.C.; Lewandowski, I.; Bangerth, F.; Jones, M.B. Comparative responses to water stress in stay-green, rapid- and slow senescing genotypes of the biomass crop, Miscanthus. New Phytol. 2002, 154, 335-345. [CrossRef]

11. Hastings, A.; Smith, P.; Clifton-Brown, J.; Taylor, G. Future biomass supply for low carbon European energy provision in a changing world. In Proceedings of the TERRAenVISION Environmental Issues Today: Scientific Solutions for Societal Issues, Barcelona, Spain, 27 January-2 February 2018.

12. Hastings, A.; Clifton-Brown, J.; Wattenbach, M.; Mitchell, C.P.; Stampfl, P.; Smith, P. Future energy potential of Miscanthus in Europe. Glob. Chang. Biol. Bioenergy 2009, 1, 180-196. [CrossRef]

13. Clifton-Brown, J.; Schwarz, K.U.; Hastings, A. History of the Development of Miscanthus as a Bioenergy Crop: From Small Beginnings to Potential Realisation. Biol. Environ. 2015, 115B, 45-57. [CrossRef]

14. Clifton-Brown, J.; Harfouche, A.; Casler, M.D.; Jones, H.D.; Macalpine, W.J.; Murphy-Bokern, D.; Smart, L.B.; Adler, A.; Ashman, C.; Awty-Carroll, D.; et al. Breeding progress and preparedness for mass-scale deployment of perennial lignocellulosic biomass crops switchgrass, Miscanthus, willow and poplar. Glob. Chang. Biol. Bioenergy 2019, 11, 118-151. [CrossRef]

15. Clifton-Brown, J.; Hastings, A.; Mos, M.; Mccalmont, J.P.; Ashman, C.; Awty-Carroll, D.; Cerazy, J.; Chiang, Y.C.; Cosentino, S.; Cracroft-Eley, W.; et al. Progress in upscaling Miscanthus biomass production for the European bio-economy with seed-based hybrids. Glob. Chang. Biol. Bioenergy 2017, 9, 6-17. [CrossRef]

16. Robson, P.; Jensen, E.; Hawkins, S.; White, S.R.; Kenobi, K.; Clifton-Brown, J.; Donnison, I.; Farrar, K. Accelerating the domestication of a bioenergy crop: Identifying and modelling morphological targets for sustainable yield increase in Miscanthus. J. Exp. Bot. 2013, 64, 4143-4155. [CrossRef] 
17. Slavov, G.; Robson, P.; Jensen, E.; Hodgson, E.; Farrar, K.; Allison, G.; Hawkins, S.; Thomas-Jones, S.; Ma, X.F.; Huang, L.; et al. Contrasting geographic patterns of genetic variation for molecular markers vs. phenotypic traits in the energy grass Miscanthus sinensis. Glob. Chang. Biol. Bioenergy 2013, 5, 562-571. [CrossRef]

18. Xi, Q.; Jezowkski, S. Plant resources of Triarrhena and Miscanthus species in China and its meaning for Europe. Plant Breed. Seed Sci. 2004, 49, 63-77.

19. Huang, L.S.; Flavell, R.; Donnison, I.S.; Chiang, Y.-C.; Hastings, A.; Hayes, C.; Heidt, C.; Hong, H.; Hsu, T.-W.; Humphreys, M.; et al. Collecting wild Miscanthus germplasm in Asia for crop improvement and conservation in Europe whilst adhering to the guidelines of the United Nations' Convention on Biological Diversity. Ann. Bot.-Lond. 2018. [CrossRef]

20. Hayes, C.; Virk, D.S. Assessing the Relative Efficacy of Polyester Pollination Bags and Crossing Tents and Isolation Chambers for Seed Harvest in Miscanthus Crosses. Int. J. Plant Breed. Genet. 2016, 10, 79-90. [CrossRef]

21. Clifton-Brown, J.C.; Senior, H.; Purdy, S.J.; Horsnell, R.; Lankamp, B.; Müennekhoff, A.-K.; Virk, D.; Guillemois, E.; Chetty, V.; Cookson, A. Investigating the potential of novel non-woven fabrics for efficient pollination control in plant breeding. PLoS ONE 2018, 13, e0204728. [CrossRef]

22. Lewandowski, I.; Clifton-Brown, J.; Trindade, L.M.; van der Linden, G.C.; Schwarz, K.U.; Muller-Samann, K.; Anisimov, A.; Chen, C.L.; Doistre, O.; Donnison, I.S.; et al. Progress on Optimizing Miscanthus Biomass Production for the European Bioeconomy: Results of the EU FP7 Project OPTIMISC. Front. Plant Sci. $2016,7$. [CrossRef]

23. Van der Weijde, T.; Huxley, L.M.; Hawkins, S.; Sembiring, E.H.; Farrar, K.; Dolstra, O.; Visser, R.G.; Trindade, L.M. Impact of drought stress on growth and quality of Miscanthus for biofuel production. Glob. Chang. Biol. Bioenergy 2017, 9, 770-782. [CrossRef]

24. Malinowska, M.; Donnison, I.S.; Robson, P.R.H. Phenomics analysis of drought responses in Miscanthus collected from different geographical locations. Glob. Chang. Biol. Bioenergy 2016. [CrossRef]

25. Stavridou, E.; Hastings, A.; Webster, R.; Robson, P. The impact of soil salinity on the yield, composition and physiology of the bioenergy grass Miscanthus x giganteus. Glob. Chang. Biol. Bioenergy 2016. [CrossRef]

26. Robson, P.R.; Donnison, I.S.; Clifton-Brown, J.C. Stem growth characteristics of high yielding Miscanthus correlate with yield, development and intraspecific competition within plots. GCB Bioenergy 2019. [CrossRef]

27. Wagner, M.; Mangold, A.; Lask, J.; Petig, E.; Kiesel, A.; Lewandowski, I. Economic and environmental performance of Miscanthus cultivated on marginal land for biogas production. Glob. Chang. Biol. Bioenergy 2019, 11, 34-49. [CrossRef]

28. Knörzer, H.; Hartung, K.; Piepho, H.P.; Lewandowski, I. Assessment of variability in biomass yield and quality: What is an adequate size of sampling area for Miscanthus? Glob. Chang. Biol. Bioenergy 2013, 5, 572-579. [CrossRef]

29. Ashman, C.; Awty-Carroll, D.; Mos, M.; Robson, P.; Clifton-Brown, J. Assessing seed priming, sowing date, and mulch film to improve the germination and survival of direct-sown Miscanthus sinensis in the United Kingdom. Glob. Chang. Biol. Bioenergy 2018, 10, 612-627. [CrossRef]

30. Clifton-Brown, J.C.; Lewandowski, I. Overwintering problems of newly established Miscanthus plantations can be overcome by identifying genotypes with improved rhizome cold tolerance. New Phytol. 2000, 148, 287-294. [CrossRef]

31. Rusinowski, S.; Krzyżak, J.; Clifton-Brown, J.; Jensen, E.; Mos, M.; Webster, R.; Sitko, K.; Pogrzeba, M. New Miscanthus hybrids cultivated at a Polish metal(loid)-contaminated site demonstrate superior stomatal regulation and reduced shoot $\mathrm{Pb}$ and $\mathrm{Cd}$ concentrations. Environ. Pollut. 2019. (In revision) [CrossRef]

32. Chae, W.B.; Hong, S.J.; Gifford, J.M.; Rayburn, A.L.; Widholm, J.M.; Juvik, J.A. Synthetic polyploid production of Miscanthus sacchariflorus, Miscanthus sinensis, and Miscanthus x giganteus. Glob. Chang. Biol. Bioenergy 2013, 5, 338-350. [CrossRef]

33. Wang, X.; Yamada, T.; Kong, F.J.; Abe, Y.; Hoshino, Y.; Sato, H.; Takamizo, T.; Kanazawa, A.; Yamada, T. Establishment of an efficient in vitro culture and particle bombardment-mediated transformation systems in Miscanthus sinensis Anderss., a potential bioenergy crop. Glob. Chang. Biol. Bioenergy 2011, 3, 322-332. [CrossRef]

34. Kim, C.; Wang, X.Y.; Lee, T.H.; Jakob, K.; Lee, G.J.; Paterson, A.H. Comparative Analysis of Miscanthus and Saccharum Reveals a Shared Whole-Genome Duplication but Different Evolutionary Fates. Plant Cell 2014, 26, 2420-2429. [CrossRef] [PubMed] 
35. Kim, C.; Zhang, D.; Auckland, S.A.; Rainville, L.K.; Jakob, K.; Kronmiller, B.; Sacks, E.J.; Deuter, M.; Paterson, A.H. SSR-based genetic maps of Miscanthus sinensis and M. sacchariflorus, and their comparison to sorghum. Theor. Appl. Genet. 2012, 124, 1325-1338. [CrossRef]

36. Swaminathan, K.; Alabady, M.; Varala, K.; De Paoli, E.; Ho, I.; Rokhsar, D.; Arumuganathan, A.; Ming, R.; Green, P.; Meyers, B.; et al. Genomic and small RNA sequencing of Miscanthus $\times$ giganteus shows the utility of sorghum as a reference genome sequence for Andropogoneae grasses. Genome Biol. 2010, 11, 2-18. [CrossRef]

37. Ma, X.F.; Jensen, E.; Alexandrov, N.; Troukhan, M.; Zhang, L.P.; Thomas-Jones, S.; Farrar, K.; Clifton-Brown, J.; Donnison, I.; Swaller, T.; et al. High Resolution Genetic Mapping by Genome Sequencing Reveals Genome Duplication and Tetraploid Genetic Structure of the Diploid Miscanthus sinensis. PLoS ONE 2012, 7. [CrossRef]

38. Davey, C.L.; Robson, P.; Hawkins, S.; Farrar, K.; Clifton-Brown, J.C.; Donnison, I.S.; Slavov, G.T. Genetic relationships between spring emergence, canopy phenology, and biomass yield increase the accuracy of genomic prediction in Miscanthus. J. Exp. Bot. 2017, 68, 5093-5102. [CrossRef]

39. Slavov, G.T.; Nipper, R.; Robson, P.; Farrar, K.; Allison, G.G.; Bosch, M.; Clifton-Brown, J.C.; Donnison, I.S.; Jensen, E. Genome-wide association studies and prediction of 17 traits related to phenology, biomass and cell wall composition in the energy grass Miscanthus sinensis. New Phytol. 2014, 201, 1227-1239. [CrossRef]

40. Clark, L.V.; Dwiyanti, M.S.; Anzoua, K.G.; Brummer, J.E.; Ghimire, B.K.; Głowacka, K.; Hall, M.; Heo, K.; Jin, X.; Lipka, A.E. Genome-wide association and genomic prediction for biomass yield in a genetically diverse Miscanthus sinensis germplasm panel phenotyped at five locations in Asia and North America. GCB Bioenergy 2019. [CrossRef]

41. Slavov, G.; Davey, C.; Bosch, M.; Robson, P.; Donnison, I.; Mackay, I. Genomic index selection provides a pragmatic framework for setting and refining multi-objective breeding targets in Miscanthus. Ann Bot-Lond. 2018. [CrossRef]

(C) 2019 by the authors. Licensee MDPI, Basel, Switzerland. This article is an open access article distributed under the terms and conditions of the Creative Commons Attribution (CC BY) license (http://creativecommons.org/licenses/by/4.0/). 